\title{
8 Spirituality at Work and Human Resource Management
}

\section{Introduction}

As most of the topics in this book are related to HRM in some way, the task to write this chapter on Spirituality at Work and HRM in general, but with limited length and without producing a lot of overlapping with other chapters of this book, poses some kind of a dilemma. I deal with this dilemma by concentrating on the employers' perspective and stances on spirituality at work - and thus opt for discussion of a narrow section of HRM only.

I start with some thoughts on definitions and conceptions of spirituality at work, and highlight the difference between individual spirituality at work and employer stances. I then go on with the categorisation of employers' stances and ask why and where spirituality at work is (or could be) relevant for managing human resources, thus asking for the conceptualization of spirituality at work within HRM. The next step is to discuss some neglected aspects on the path of impact between spirituality and HRM outcomes, and finish with some summarising thoughts on what would be nice to see in research on spirituality at work and HRM in 10 years.

\section{Definitions and Conceptual Levels of Spirituality at Work}

Up to now, there still are intensive and ongoing debates - "with no end in sight" (Miller \& Ewest, 2015) - about the definition of workplace spirituality or - as I prefer to term it - spirituality at work and the related levels and fields (Hill et al., 2000; Miller \& Ewest, 2015; Loo, 2017; Heliot et al., 2020; Pfaltzgraff-Carlson, 2020). Ongoing debates on terms, definitions and conceptualizations imply that we still do not agree on what to look for and at what levels and fields in spirituality at work. To get a clear view on the relationship between HRM and spirituality at work, three aspects have to be clarified: first the relation between religion and spirituality, second the definition of spirituality at work in relation to spirituality in general, and third the relation between individual spirituality and employers' stances.

I define spirituality on the individual level, as individual needs and traits, attitudes and behaviours related to (McGhee \& Grant, 2017; Mitroff et al., 1999; Sheep, 2006) 
- (the search for) transcendence and connectedness with a power higher than the self and/or a greater whole,

- connectedness with other human beings,

- meaning in life and

- personal development of the human being between birth and death as existential poles of life.

The attitudes and behaviours may or may not anchor in a specific religion, for example in defining the higher power as God (as in Christianity and Jewry) or as Allah (as in Islam). If so, spirituality is religious spirituality - and may be alternatively termed as religiosity. Religious spirituality unfolds on religion as a collective, often heavily institutionalised basis. However, there are other, nonreligious forms of spirituality without a specific religion as a basis. Thus, in this definition, spirituality is a generic term and covers a broad spectrum of forms - from purely religious spirituality to purely nonreligious spirituality and many mixed forms in between. A related definition of spirituality as a generic term - including irreligious, mixed and religious forms - is used by several authors (e.g. Hill et al., 2000; Krishnakumar \& Neck, 2002; Miller \& Ewest, 2015).

However, this definition of spirituality as a generic term including religious and nonreligious spirituality is not unanimously shared (Miller \& Ewest, 2015), as many other authors sharply delineate spirituality and religiosity (Duffy, 2006; Joelle \& Coelho, 2019; Mitroff et al., 1999; Petchsawang \& Duchon, 2009; Zinnbauer \& Pargament, 2005). So why use the term as a generic term in the context of HRM? Delineating spirituality and religiosity in analysing, describing and understanding the effects and antecedents of spirituality in theoretical and empirical research and in HRM in practice poses some severe - and in my view unsolvable - difficulties (Hill et al., 2000): Individuals may follow a specific religion in some but not in all aspects of their spirituality. For example, they may apply prayers of their specific religion and attend services of their church, but have normative ideas about living together with other persons that deviate strongly from official doctrine, and attend spiritual meditation classes without reference to religion, too. In the same vein, religious and spiritual behaviour and practices cannot be excised clearly, for example prayer as a religious practice and meditation as a spiritual practice: How would we, for instance, assign the Christian prayer of the heart, which is a form of religious meditation, to either spirituality or religiosity? How do we know what kind of spiritual meditation is performed during a prayer? Probably even religious individuals themselves will often not know exactly whether their attitudes and behaviour conform to official religious doctrine of a specific religious convention - and/or whether their subjective interpretation is already outside official doctrine or contains a broad mixture of elements from different traditions. And even within religious communities, there often are more than one official interpretations and strands of argumentation on questions of faith - so that even official personnel of the religious community will sometimes not 
be able to clearly separate spirituality (including all individual differences) and religiosity (with its strong collective and normative focus). If all this together is spiritual life, then a sharp separation between religious and spiritual practices, attitudes and behaviours applied by researchers, and put into practice in empirical research, is not possible.

Turning to the definition of workplace spirituality or spirituality at work, one may on the one hand ask whether and how individual spirituality gains importance at work and for work, and on the other hand, what stances employers develop with regard to individual spirituality at the workplace and within the organisation.

We should first note that individuals, and not the organisation, may have spiritual traits and spiritual needs and express their spirituality in many different attitudes and behaviours at work, at the workplace and within the organisation. For example, individuals can express their spirituality in meditation, yoga or prayer, in eating and drinking behaviour during fasten seasons or in general, in wearing religious clothes or jewellery, or in communications with colleagues, supervisors and clients that express spiritual or religious attitudes and convictions. Employees may interpret their work as individual calling or as important part of their search for meaning and community with other human beings. They may derive decisions in a transcendent context, develop their own personality in the work context as part of their personal spiritual journey or try to persuade and proselyte others with regard to their faith (Gebert et al., 2013; Loo, 2017; McGhee \& Grant, 2017). In this perspective, I speak of spirituality at work when individuals bring their individual spirituality to work.

An aspect often not analysed is that even highly spiritual individuals may or may not bring spiritual needs to the workplace, deploy their spiritual traits at work or not, express their spirituality at the workplace or solely in other fields of life. I elaborate on this aspect later on.

Turning to employer stances on spirituality at work, let me first note that employees (with their individual spiritual traits and needs, and their desires and decisions to express spirituality at work in specific attitudes and behaviours) work in differing organisational frameworks and under differing stances and personnel policies of their employers - in general and with regard to spirituality, too. Some authors define workplace spirituality at this organisational level. For example, Ashmos and Duchon define spirituality at work as the recognition of the employer or decision makers in the firm that employees have an inner life of the soul and the spirit which is nourished by meaningful work and community with other persons (Ashmos \& Duchon, 2000, p. 137). Krahnke et al. describe workplace spirituality as a framework of organisational values which are anchored in the culture of the firm and which support and facilitate experiences of transcendence and feelings of community with others resulting in wholeness and joy at work (Krahnke et al., 2003). Both teams of authors define spirituality at work on the side of the employer or firm, and as a positive stance with regard to religion. However, there is a wide array of possible employer stances with 
regard to spirituality at work - not only a positive or pro-spirituality one. Defining spirituality at the individual level and employer's stances with regard to individual spirituality or frameworks at the organisational level helps to clarify the levels of definition and to differentiate employer's stances.

Researchers have, to our best knowledge, not analysed the stances of employee representatives (as works councils or unions) with regard to workplace spirituality yet. However, there are already some conceptual approaches to classify employers' stances (Giacalone \& Jurkiewicz, 2010; Mazumdar \& Mazumdar, 2005; Mitroff et al., 1999; Ashfort \& Pratt, 2010; Miller \& Ewest, 2015; Tabesh \& Jolly, 2019). These classifications are based on partially different criteria, some use more than one criterion at the same time and/or mix these together, sometimes in an unsystematic manner (Miller \& Ewest, 2015; Alewell \& Moll, 2021b). One of the newer classifications, developed out of a critique and advancement of the former classifications, is that by Miller and Ewest (2015). Using faith as generic term with the two sub-dimensions of religiosity (or religious spirituality) and spirituality (nonreligious spirituality), they classify employers as faith-avoiding, faith-safe, faith-friendly und faith-based (Miller \& Ewest, 2015). Faith-based organisations have been founded with a spiritual goal or aim or in a specific faith tradition, often that of their founder. Faith-avoiding organisations try to keep the topic of faith out of their business as far as possible and stay neutral as much as possible. Faith-safe organisations concentrate on compliance with the law. They accommodate faith-based requests by employees as far as they have to according to law and jurisdiction, but not any further. Faith-friendly organisations secure compliance with the law and fair accommodation of requests, too, but moreover, they support and welcome free expression of individual spirituality at work. While this classification is the most advanced typology we know of and an important contribution to research on spirituality at work, there are still some problems - food for thought during the next ten years of research:

- An important focus of the classification is how positive (or embracing) or negative (or rejecting) the employer's stance with regard to faith (spirituality in our terms) is (Miller \& Ewest, 2015). However, the classification does not allow an unambiguous classification of the degree of negativity or positivity of the employer's stance. For example, employers can be faith-safe and faith-avoiding at the same time. If the law of a country grants some right of religious freedom at work, employers can possibly not completely avoid the topic of spirituality at work. And even if their attitude is in essence faith-avoiding, employees may request religious freedom and force employers to deal with the topic, if not voluntarily, then by juridical pressure, and become eventually faith-safe in their decisions and practices, because courts may force them to. Alternatively, to take another example, faith-based organisations may also be faith-friendly, encouraging expression of spirituality by members of all faith traditions, but still being founded and imprinted in a specific tradition and employing a majority of employees following this tradition. 
- The employer's stance with regard to religious spirituality and to nonreligious spirituality may be very different (Alewell \& Moll, 2021b; Heliot et al., 2020) potentially as a reaction to laws that regulate and protect aspects of religious freedom, but do often not refer to nonreligious spirituality.

- The antecedents and effects of the specific employers' stances and the related contextualisation in different fields of HRM are not a systematic part of the conceptualization yet. Decision makers in organisations may expect positive and/or negative effects of spirituality in different realms - for example, effects of nonreligious spirituality on health, stress management, creativity and innovation, or effects of religious spirituality on conflict, discrimination, diversity, and retention management. While Miller and Ewest explicitly integrate antidiscrimination and compliance with the law into their analysis (Miller \& Ewest, 2015), the dominant contextualisation of employer's stances with regard to religious or non-religious faith in different HRM sub-functions still needs to be discussed. Alewell and Moll differentiate between three employers' perspectives focused on spiritual diversity, on spiritual needs and their satisfaction, and/or on spirituality as a capability enhancing performance, creativity and stress resilience. (Alewell \& Moll, 2021b). Depending on the dominant perspective(s) and contextualisations, employers will expect different HRM effects and take on different stances. Overall, for empirical research, we need to enrich the classifications of employer stances.

Our own small-scale-qualitative-study for Germany hints - in accordance with expectations of researchers for the United States of America (Mitroff et al., 1999; Miller \& Ewest, 2015) - at widespread faith-avoiding and faith-safe stances for religious spirituality, and much more positive stances for nonreligious spirituality (Alewell \& Moll, 2019a, 2021a). However, up to now, our empirical knowledge about employers' stances with regard to spirituality at work, about antecedents of these attitudes and employers expectations on effects of spirituality at work is very small - and there is a lot research to do during the next ten years. Neither do we know in which HR fields (for example diversity management, recruiting, retention management, personnel development) employers expect effects and under which perspective they contextualise spirituality at work, nor do we know how positive or negative these specific expectations are. And finally, research is necessary if and how far these expectations coin the employer's stances - or if some other factors, for example cultural aspects in different countries, dominantly influence these. Summarising, to gain a viable and sound basis for quantitative empirical investigations, existing typologies on employers' (and works councils' and unions') stances with regard to spirituality at work and related instruments of measurement have to be developed (further), complemented by the differing perspectives and taking into account potential differences between religious and nonreligious spirituality. 


\section{Relevance of Spirituality for Different Fields of HRM}

There has been and there still is a discussion on the relevance of spirituality at work for Human Resource Management or for organisations in general. At first sight, the impartial observer of practice may - in spite of the many research contributions - ask what spirituality and work have to do with each other - even more so in the face of a lively discussion on secularisation for many developed and industrialised societies (Pickel, 2011) his first blush impression may intensify if one perceives the near non-existence of this topic at an explicit level in many large firms. Spirituality and work may thus appear as two completely unrelated fields (Wicks, 2014; Mitroff et al., 1999; Gebert et al., 2013) where neutral or negative employer and employee stances on spirituality at work are to be expected for the majority of organisations and persons.

However, at second blush and from the perspective of the informed observer, the picture is much richer and more colourful, and there are good reasons to concern HRM and/or management in general with spirituality at work (Miller \& Ewest, 2015). Neal states that there is a trend in modern HRM concepts to utilise more and more of employees' resources: First, there was an increasing utilisation of physical resources, then of mental-cognitive resources, and eventually psychic and emotional resources were deployed at work. Nowadays, the next and final step is to focus on spiritual resources, on the soul of employees (Neal, 2013). And some authors (Miller \& Ewest, 2013, 2015; Alewell \& Moll, 2019b) show that (and how) a stronger focus of HRM on spirituality connects smoothly to recent strands of discussion, for example to

- discussions on holistic work-life-balance, where up to now the "life" aspect was strongly defined by family and leisure time in a reductionist way, but may in future be supplemented by spirituality issues, too,

- discussions on diversity and anti-discrimination, with a strong focus on age, gender, nationality, ethnicity as criteria up to now, with a deeper focus on religion and spirituality yet to come into focus (Alewell \& Rastetter, 2019),

- debates with regard to differences between preferences and needs of persons belonging to different generations, with typical spiritual needs for meaning and community being hypothesised as more important for younger generation cohorts (see Alewell \& Brinck, 2017, with a critical stance to such hypotheses),

- ideas and thoughts regarding state of the art leadership, centring in theory around transformational and charismatic leadership styles - with the central concepts of charisma and visions being intensely linked to essentially spiritual topics (Oh \& Wang, 2020), a tendency that some managers seek counselling and help in religious institutions (Alewell \& Müller, 2019); and discussions on radical uncertainty and "unverfügbarkeit" as a linking pin between theology and management (Huppenbauer, 2008; Huppenbauer \& Grand, 2007);

- compliance efforts of organisations which are up to now often concerned with data protection, corruption, labour and social security law and basic human 
rights, but which could be focused on freedom of religious expression and protection against discrimination in all fields of HRM, too (Miller \& Ewest, 2015; Meyer, 2020; Hoppe \& Groffy, 2019),

- values, ethical behaviour and responsibility are discussed in the contexts of corporate governance, compliance and ethical leadership. Religion is one important source of such values and behaviours.

- Moreover, very topical, there is a new influence with the COVID-19 pandemic. Topics of illness, danger to life, death and dying with all the related deep emotions and existential importance to human beings sweep into the organisational context. And wherever existential questions come to the foreground, individual spiritual - and especially religious - resources may become more important than in the past to cope with such challenges.

Research and discussion of the past decades, thus, show that a deeper focus on employees' spirituality is already more or less implicitly prepared in many HRM strands of discussion and could tie in there, but has yet to unfold and become more explicit. And if so, spirituality at work may get into focus under very different topics, HRM themes and terms, for example, in the context of compliance, anti-discrimination and diversity, the context of performance, creativity and stress management, or of recruitment and retention management, in the context of leadership values, or of health management. It may also be contextualised and promoted under very different terms, aims and goals and with very different instruments and policies. Right now, our theoretical and empirical research and existing classifications of employer stances do not mirror this broad spectrum of HRM relevance, and for many countries, for example for Germany, there are no specific results yet, if, and how, with what aims and goals, expectations and contextualisation employers handle spirituality at work.

However, researchers already discuss some of these issues in separated strands of research, for example discrimination and diversity.

\section{Religion and Spirituality, Discrimination and Diversity}

In a partially separated strand of discussion, religion is discussed as a potential criterion of discrimination and diversity management (Bennett, 2008; Ghumman et al., 2013; Benefiel et al., 2014); for Germany (Hoevels, 2015), for France (Hennekam et al., 2018)). However, for example in Germany, religion is only seldom used as diversity criterion (for a conceptual overview, Alewell \& Rastetter, 2019; for reasons, Gebert et al., 2013). Our knowledge on the situation in different countries is still small, and the call of (Benefiel et al., 2014, p. 184) for more research on religion as diversity criterion is still topical. 
For example, in Germany, the freedom of (expression of) religion is guaranteed in the constitution, but so is the property right of the employer. Because both rights may conflict, courts have developed guidelines in their jurisdiction how to balance the employer's rights and the employee's right, which help to decide under which conditions the employer is allowed to forbid or restrict expressions of religion at work (Alewell \& Rastetter, 2019; Meyer, 2020). There are juridical conflicts with regard to religious garment at work, religious signs as decoration in office rooms and the terms of use of rooms of silence (for an overview of German jurisdiction, Meyer, 2020; Hoppe \& Groffy, 2019) but we do not know how often such conflicts arise outside juridical conflicts. Moreover, religious and nonreligious spirituality may show strong differences with regard to diversity and discrimination - as it is only religious spirituality that is protected by the constitution and the General Law on equality (AGG, Allgemeines Gleichstellungsgesetz).

In research, discrimination as a potential negative effect is contrasted with diversity which is often interpreted as positive due to resulting higher creativity and capability to innovate (Hanappi-Egger, 2015; Rastetter \& Dreas, 2016). However, there are multiple diversity criteria, for example age, gender, nationality or ethnicity, and religion, and how organisations design their diversity management with regard to religion and spirituality and the combination of diversity criteria including religion is more or less open. As far as we know, for example in Germany, religion is a diversity criteria used only very seldom. There are a number of potential reasons (Alewell \& Rastetter, 2019): Fear of conflict, of discrimination, and of division of employees into subgroups; lack of a sound data basis, and the assessment that religion may hamper organisational rationality and performance calculus (Alewell \& Rastetter, 2019; Gebert et al., 2013). Which of these reasons are empirically valid and important remains to be analysed in the future.

In ten years, it would be nice to see a more thorough integration between the strands of discussion on discrimination and diversity and discrimination on the one hand and on spirituality at work on the other hand. This would help to better integrate the discussion on potential benefits and dangers, on positive and negative effects of spirituality at work, and give a better basis to look at the effects of both religious and nonreligious spirituality. Additionally, the longstanding research traditions and results of the sociology of religion could help to better understand the positive and negative effects religion may have in institutions and organisations (Alewell \& Moll, 2021b).

\section{Spirituality’s Path to Impact}

As already shown, spirituality can be conceptualised as an important individual resource or trait, or as an individual need. There is much research that analyses whether and how using the resource (or satisfying the need) affects individual and 
organisational HRM outcomes. For instance, researchers analyse the relation with performance (Garcia-Zamor, 2003; Duchon \& Plowman, 2005; Houghton et al., 2016), job satisfaction (King \& Williamson, 2005; Milliman et al., 2003; Garg, 2017; Mensah et al., 2019), social behavior (Pawar, 2009; Houghton et al., 2016), creativity (Krishnakumar \& Neck, 2002; Ashmos \& Duchon, 2000; Mitroff et al., 1999), initiative and engagement (Whitaker \& Westerman, 2014), well-being of employees (Fry \& SLOCUM, 2008), and further aspects as general life satisfaction, burn-out (Yang \& Fry, 2018; Kolodinsky et al., 2008) or ethical behavior (Cavanagh, 1999; GarciaZamor, 2003; McGhee \& Grant, 2017). Yet, effects are sometimes ambivalent and instable, (with regard to job satisfaction, see, for example, King \& Williamson, 2005; Gupta et al., 2014; Milliman et al., 2003; Garg, 2017; Mensah et al., 2019; for ethical behaviour McGhee \& Grant, 2017) and much more research on moderators and mediators of effects and other reasons for ambivalence of results is needed.

One important aspect could be, that many research studies on effects of individual spirituality at work (for an exception see (King \& Williamson, 2005; Alewell et al., 2020) do not explicitly differentiate between spirituality as an attitude or need, between the desire of the employees to express spirituality at work and between the factual expression of spirituality at work in attitudes and behaviour. Often, authors (implicitly or explicitly) analyse spirituality as a personal trait or characteristic, which may have positive effects more or less irrespective of context.

However, individuals may have the wish or desire to satisfy their spiritual needs at the workplace or live this need in other fields of their life. If they have the wish to express spirituality at work, they may nevertheless decide against it or feel unable to do so, for example because they fear discrimination or perceive their working context as hostile against spiritual expression. In short, we need to differentiate between

- traits and/or needs,

- the desire to express their (religious or nonreligious) spirituality or satisfy their needs in the specific context of work, and

- the actual expression of their (religious or nonreligious) spirituality at work

(King \& Williamson, 2005; Alewell et al., 2020; Heliot et al., 2020; Gebert et al., 2013 with reference to activation of religious identities).

These specific aspects of individual spirituality are important for different functions of HRM: For example, traits and needs may become especially relevant in recruiting and retention management, but the desire to express spiritual needs at work and the resulting behaviour and communication may be more important for developing and leading employees and for cooperation in diverse teams and conflict management. The actual expression may be especially relevant for teamwork as well as in diversity and conflict management. As a result, we need much more research on the full path - employees' spiritual needs or traits, their desire to express their religious and/or nonreligious spirituality in different contexts, their 
actual expression of spirituality at the workplace and the relationship between these individual-level-concepts, and on factors influencing them. For example, individual perceptions of employer stances or organisational culture with regard to individual spirituality at the workplace may influence the desire to express individual spirituality at the workplace or its factual expression. Perceived religious discrimination or cultural elements as the degree of laicism may influence these elements, coining the degree of publicity or privacy with regard to the expression of religion in a country. Additionally, the tasks and the structure of the workplace may be important - high autonomy and a high degree of decision latitude may open up a field of opportunities and responsibility in which individual spirituality unfolds as a need, or is perceived as especially useful resource. A related perspective is that in "weak situations" individuals may use their spirituality as an important resource, while in a "strong situation" with low autonomy and low discretion the effects of spirituality may be of much less relevance. It would be nice to see more results on these topics in ten years.

\section{Future Development of the Field and Open Research Questions}

Summarising some of the arguments with regard to the general development of the field into the future, I develop my personal "bucket list" of what progress to welcome in the near future based on the previous considerations:

- A quick development to more clarity in central terms as a basis for sound empirical research (see also section on terms and definitions above): more clarity in terms and definitions, and levels of analysis with regard to spirituality, religion and religiosity, with an integrative view on religious and nonreligious spirituality and a clear distinction between employer-sided and employee-sided concepts;

- a clear separation between individual spirituality as a trait and/or as a need, the desire to satisfy this need in the specific context of work and the actual expression of spirituality at work, and research on the path between these variables,

- a much more realistic view on spirituality at work in firms which takes spirituality seriously as a productive element with relevance for HRM in research and practice on the one hand - but does not close the eyes to the darker sides connected with spirituality on the other hand, for example, conflict and discrimination and related fears, negative stereotypes, potentials to invade the privacy of the employees, or the danger to exploit individual resources of the soul for purely economic reasons,

- a closer tying in with the sociology of religion, lifting up the treasures of these long standing research traditions to more intensive attention within the workplace spirituality movement, especially on positive and negative effects of religion 
and religiosity in collectives and institutions (Pickel, 2011; Alewell \& Moll, 2021a) - ideas and results that may be transferable to firms and organisations.

- Much more large-scale empirical research on spirituality at work for the different regions, countries or cultural spheres, and for all aspects and facets of the topic (see below for a list of more specific research questions).

Concretising these aspects in more detail and with higher specificity, there are some bundles of open research questions:

1. How frequent and how strong are individual religious and nonreligious spirituality in employees? Do specific groups of employees differ with respect to this question? Do employees desire to bring and express their individual (religious and/or nonreligious) spirituality to/at work? How frequent and how strong is this desire? Do employees prefer to keep their spirituality a private matter? Why or why not? Do we find more of a trait relation or more of a need-satisfaction relation? Is spirituality at work "relevant" with regard to the frequency employees bring and express their spirituality to/at work?

2. Does the desire to bring and/or express spirituality at work depend on the employees' experience of religious or spiritual discrimination? How frequent and intense and in which fields or for which groups of employees do such experiences exist? How do employers and works councils react, what do they do to prevent such discrimination?

3. How can we classify and conceptualise employers' stances with regard to spirituality at work in richer classifications? How can we classify and conceptualise employee representatives' (as works councils' or unions') stances with regard to spirituality at work? Which stances of employers, work councils and unions are prevalent under which conditions?

4. Which spirituality-at-work-related policies and instruments do employers implement, and what do they expect with regard to the effects of these instruments and policies? Do these policies and instruments differ between religious and nonreligious spirituality?

5. How do employers contextualise their stances and activities on spirituality at work and does this differ between religious and nonreligious spirituality - as a distinct HRM function, or integrated in other HRM sub-functions, for example, in diversity management, in organisational health management, in recruiting or retention management or as part of compliance activities? When and why (not) do employers deploy religious and/or nonreligious spirituality as a criterion of diversity management? What is the attitude of works councils?

6. Which relations between (religious and nonreligious) spirituality and HRM outcome variables exist in which countries and cultural spheres? Which moderators and mediators are active in these relations? Do these relations depend on the tasks performed and/or the level or autonomy of the employee? 


\section{References}

Alewell, D., \& Brinck, K. L. (2017). Generationsunterschiede in den Vorstellungen über „gute Arbeit" - Fakt oder Fiktion? In H. Surrey \& V. Tiberius (Eds.), Die Zukunft des Personalmanagements. Herausforderungen, Lösungsansätze und Gestaltungsoptionen (1st ed., pp. 79-91). vdf Hochschulverlag AG an der ETH Zürich.

Alewell, D., Brinck, K. L., \& Moll, T. (2020). (How) does religiousness impact on job satisfaction? Unpublished Manuscript, Submitted for Review.

Alewell, D., \& Moll, T. (2019a). Religion, Religiosität und Spiritualität am Arbeitsplatz in deutschen Unternehmen. In D. Alewell \& W. Matiaske (Eds.), Standards guter Arbeit.Disziplinäre Positionen und interdisziplinäre Perspektiven (1. Auflage, pp. 107-138). Nomos. https:// doi.org/10.5771/9783845299310-107

Alewell, D., \& Moll, T. (2019b). Religiosität und Spiritualität am Arbeitsplatz in deutschen Unternehmen. In D. Alewell \& W. Matiaske (Eds.), Standards guter Arbeit.Disziplinäre Positionen und interdisziplinäre Perspektiven (1. Auflage, pp. 107-137). Nomos.

Alewell, D., \& Moll, T. (2021a). An exploratory study of spirituality in German enterprises. Management Revue. Socio Economic Studies, 1.

Alewell, D., \& Moll, T. (2021b). Employers' strategies on faith and spirituality at work: Conceptual thoughts for Germany. In E. Pio, R. Kilpatrick, \& T. Pratt (Eds.), Reimagining faith and management. The impact of faith in the workplace.

Alewell, D., \& Müller, B. (2019). Was suchen Führungskräfte im Kloster? In B. FeldbauerDurstmüller, T. Wolf, \& M. Neulinger OSB (Eds.), Unternehmen und Klöster (pp. 265-289). Springer Fachmedien Wiesbaden.

Alewell, D., \& Rastetter, D. (2019). On the (ir)relevance of religion for human resource management and diversity management: A German perspective. German Journal of Human Resource Management: Zeitschrift Für Personalforschung, 34(1), 9-31. https://doi.org/10.1177/ 2397002219882399

Ashfort, B. E., \& Pratt, M. G. (2010). Institutional spirituality: An oxymoron? In R. A. Giacalone \& C. L. Jurkiewicz (Eds.), Handbook of Workplace Spirituality and Organizational Performance (2nd ed., pp. 44-58). Taylor and Francis Routledge.

Ashmos, D. P., \& Duchon, D. (2000). Spirituality at work: A conceptualization and measure. Journal of Management Inquiry, 9(2), 134-145. https://doi.org/10.1177/105649260092008

Benefiel, M., Fry, L. W., \& Geigle, D. (2014). Spirituality and religion in the workplace: History, theory, and research. Psychology of Religion and Spirituality, 6(3), 175-187.

Bennett, M. F. (2008). Religious and spiritual diversity in the workplace. In M. A. Moodian (Ed.), Contemporary Leadership and Intercultural Competence: Exploring the Cross-Cultural Dynamics Within Organizations (pp. 45-60). SAGE PUBN.

Cavanagh, G. F. (1999). Spirituality for managers: Context and critique. Journal of Organizational Change Management, 12(3), 186-199. https://doi.org/10.1108/09534819910273793

Duchon, D., \& Plowman, D. A. (2005). Nurturing the spirit at work: Impact on work unit performance. The Leadership Quarterly, 16(5), 807-833. https://doi.org/10.1016/ j.leaqua.2005.07.008

Duffy, R. D. (2006). Spirituality, religion, and career development: Current status and future directions. The Career Development Quarterly, 55(1), 52-63. https://doi.org/10.1002/ j.2161-0045.2006.tb00004.x

Fry, L. W., \& SLOCUM, J. W. (2008). Maximizing the triple bottom line through spiritual leadership. Organizational Dynamics, 37(1), 86-96. https://doi.org/10.1016/j.orgdyn.2007.11.004

Garcia-Zamor, J.-C. (2003). Workplace spirituality and organizational performance. Public Administration Review, 63(3), 355-363. https://doi.org/10.1111/1540-6210.00295 
Garg, N. (2017). Workplace spirituality and employee well-being: An empirical exploration. Journal of Human Values, 23(2), 129-147. https://doi.org/10.1177/0971685816689741

Gebert, D., Boerner, S., Kearney, E., King, J., Zhang, K., \& Song, L. J. (2013). Expressing religious identities in the workplace. Analyzing a neglected diversity dimension. Human Relations, 67(5), 543-563.

Ghumman, S., Ryan, A. M., Barclay, L. A., \& Markel, K. S. (2013). Religious discrimination in the workplace: A review and examination of current and future trends. Journal of Business and Psychology, 28(4), 439-454. https://doi.org/10.1007/s10869-013-9290-0

Giacalone, R. A., \& Jurkiewicz, C. L. (2010). The science of workplace spirituality. In R. A. Giacalone \& C. L. Jurkiewicz (Eds.), Handbook of Workplace Spirituality and Organizational Performance (2nd ed., pp. 3-26). Taylor and Francis Routledge.

Gupta, M., Kumar, V., \& Singh, M. (2014). Creating Satisfied Employees Through Workplace Spirituality: A Study of the Private Insurance Sector in Punjab (India). Journal of Business Ethics, 122(1), 79-88. https://doi.org/10.1007/s10551-013-1756-5

Hanappi-Egger, E. (2015). Diversität, Diversifizierung und (Ent)Solidarisierung. Eine Standortbestimmung der Diversitätsforschung im deutschen Sprachraum. Springer VS.

Heliot, Y., Gleibs, I. H., Coyle, Adrian, Rousseau, D. M., \& Rojon, Celine. (2020). Religious identity in the workplace: A systematic review, research agenda, and practical implications. Human Resource Management, 59, 153-173.

Hennekam, S., Peterson, J., Tahssain-Gay, L., \& Dumazert, J.-P. (2018). Managing religious diversity in secular organizations in France. Employee Relations, 40(5), 746-761. https://doi.org/ 10.1108/ER-06-2017-0142

Hill, P. C., Pargament, K. I., Hood, R. W. Jr., MCullough, M. E., Swyers, J. P., Larson, D. B., \& Zinnbauer, B. J. (2000). Conceptualizing religion and spirituality: Points of commonality, points of departure. Journal for the Theory of Social Behaviour, 30(1), 51-77.

Hoevels, N. (2015). Muslime in der aktuellen Rechtsprechung zum Arbeitsrecht. In M. Khalfaoui \& M. Möhring-Hesse (Eds.), Eine Arbeitsgesellschaft - Auch für Muslime.Interdisziplinäre und interreligiöse Beiträge zur Ewerbsarbeit (pp. 83-93). Waxmann Verlag.

Hoppe, C., \& Groffy, G. (2019). "Solange IV”? Religiöse Symbole am Arbeitsplatz im Spiegel der deutschen Rechtsprechung und des EuGH. Arbeitsrecht Aktuell, 211-213.

Houghton, J. D., Neck, C. P., \& Krishnakumar, S. (2016). The what, why, and how of spirituality in the workplace revisited: A 14-year update and extension. Journal of Management, Spirituality \& Religion, 13(3), 177-205. https://doi.org/10.1080/14766086.2016.1185292

Huppenbauer, M. (2008). Handeln im Kontext von Unverfügbarkeit. Probleme des Wissenstransfers zwischen Management und Theologie.

Huppenbauer, M., \& Grand, S. (2007). Managementforschung und theologische Ethik im Diskurs: Beobachtungen und Reflexionen aus der "Trading Zone" von Management und Religion. Zeitschrift Für Evangelische Ethik, 51(2), 129-145.

Joelle, M., \& Coelho, A. M. (2019). The impact of spirituality at work on workers' attitudes and individual performance. The International Journal of Human Resource Management, 30(7), 1111-1135. https://doi.org/10.1080/09585192.2017.1314312

King, J. E., \& Williamson, I. O. (2005). Workplace Religious Expression, Religiosity and Job Satisfaction: Clarifying a Relationship. Journal of Management, Spirituality \& Religion, 2(2), 173-198. https://doi.org/10.1080/14766080509518579

Kolodinsky, R. W., Giacalone, R. A., \& Jurkiewicz, C. L. (2008). Workplace values and outcomes: Exploring personal, organizational, and interactive workplace spirituality. Journal of Business Ethics, 81(2), 465-480. https://doi.org/10.1007/s10551-007-9507-0 
Krahnke, K., Giacalone, R. A., \& Jurkiewicz, C. L. (2003). Point-counterpoint: Measuring workplace spirituality. Journal of Organizational Change Management, 16(4), 396-405. https://doi.org/ 10.1108/09534810310484154

Krishnakumar, S., \& Neck, C. P. (2002). The "what", "why" and "how" of spirituality in the workplace. Journal of Managerial Psychology, 17(3), 153-164. https://doi.org/10.1108/ 02683940210423060

Loo, M. K. L. (2017). Spirituality in the workplace: Practices, challenges, and recommendations. Journal of Psychology and Theology, 45(3), 182-204. https://doi.org/10.1177/ 009164711704500303

Mazumdar, S., \& Mazumdar, S. (2005). How Organizations Interface with Religion: A Typology. Journal of Management, Spirituality \& Religion, 2(2), 199-220. https://doi.org/10.1080/ 14766080509518580

McGhee, P., \& Grant, P. (2017). The transcendent influence of spirituality on ethical action in organizations. Journal of Management, Spirituality \& Religion, 14(2), 160-178. https://doi. org/10.1080/14766086.2016.1268539

Mensah, H. K., Asiamah, N., \& Azinga, S. A. (2019). The association between nurses' religiousness and job satisfaction. International Journal of Ethics and Systems, 35(3), 426-443. https://doi. org/10.1108/IJOES-04-2018-0061

Meyer, C. (2020). Das Kopftuch am Arbeitsplatz und unternehmerische Neutralitätskonzepte: Wie verändert europäisches Gleichbehandlungsrecht den Umgang mit der Religionsfreiheit in Arbeitsverhältnissen zwischen Privaten? Europäische Zeitschrift Für Arbeitsrecht, 206-223.

Miller, D. W., \& Ewest, T. (2013). The Present State of Workplace Spirituality: A Literature Review Considering Context, Theory, and Measurement/Assessment. Journal of Religious \& Theological Information, 12(1-2), 29-54. https://doi.org/10.1080/10477845.2013.800776

Miller, D. W., \& Ewest, T. (2015). A new framework for analyzing organizational workplace religion and spirituality. Journal of Management, Spirituality \& Religion, 12(4), 305-328. https://doi. org/10.1080/14766086.2015.1054864

Milliman, J., Czaplewski, A. J., \& Ferguson, J. \%J J. of organizational change management. (2003). Workplace spirituality and employee work attitudes: An exploratory empirical assessment. 16(4), 426-447.

Mitroff, I. I., Mitroff, I., \& Denton, E. A. (1999). A spiritual audit of corporate America: A hard look at spirituality, religion, and values in the workplace (First Edition, Vol. 140). Jossey-Bass.

Neal, J. (2013). Introduction. In J. Neal (Ed.), Handbook of Faith and Spirituality in the Workplace. Emerging Research and Practice (pp. 3-18). Springer.

Oh, J., \& Wang, J. (2020). Spiritual leadership: Current status and Agenda for future research and practice. Journal of Management, Spirituality \& Religion, 17(3), 223-248. https://doi.org/ $10.1080 / 14766086.2020 .1728568$

Pawar, B. S. (2009). Individual spirituality, workplace spirituality and work attitudes: An empirical test of direct and interaction effects. Leadership \& Organization Development Journal, 30(8), 759-777. https://doi.org/10.1108/01437730911003911

Petchsawang, P., \& Duchon, D. (2009). Measuring workplace spirituality in an Asian context. Human Resource Development International, 12(4), 459-468. https://doi.org/10.1080/ 13678860903135912

Pfaltzgraff-Carlson, R. (2020). Reconceptualizing organizational spirituality: Theological roots for scientific and practical fruits. Journal of Management, Spirituality \& Religion, 17(3), 249-269. https://doi.org/10.1080/14766086.2020.1762712

Pickel, V. (2011). Religionssoziologie. Eine Einführung. Springer VS. 
Rastetter, D., \& Dreas, S. A. (2016). Diversity Management als eine betriebliche Strategie.

In K. Fereidooni \& A. P. Zeoli (Eds.), Managing Diversity. Die diversitätsbewusste Ausrichtung des Bildungs- und Kulturwesens, der Wirtschaft und Verwaltung (pp. 319-339). Springer VS (Research).

Sheep, M. L. (2006). Nurturing the Whole Person: The Ethics of Workplace Spirituality in a Society of Organizations. Journal of Business Ethics, 66(4), 357-375. https://doi.org/10.1007/s10551006-0014-5

Tabesh, P., \& Jolly, P. M. (2019). Beyond the law: Processes underlying religious accommodation decisions. Management Decision, 57(5), 1254-1266. https://doi.org/10.1108/MD-11-2017-1087

Whitaker, B. G., \& Westerman, J. W. (2014). Linking spirituality and values to personal initiative through psychological empowerment. Journal of Management, Spirituality \& Religion, 11(3), 269-291. https://doi.org/10.1080/14766086.2014.905221

Wicks, A. (2014). Stakeholder theory and spirituality. Journal of Management, Spirituality \& Religion, 11(4), 294-306. https://doi.org/10.1080/14766086.2014.917984

Yang, M., \& Fry, L. W. (2018). The role of spiritual leadership in reducing healthcare worker burnout. Journal of Management, Spirituality \& Religion, 15(4), 305-324. https://doi.org/ 10.1080/14766086.2018.1482562

Zinnbauer, B. J., \& Pargament, K. I. (2005). Religiousness and Spirituality. In R. F. Paloutzian \& C. L. Park (Eds.), Handbook of the psychology of religion and spirituality (pp. 21-42). Guilford Press. 
